\title{
How are necroptosis, immune dysfunction, and motoneuron death connected in amyotrophic lateral sclerosis?
}

\author{
Jian-Feng Liư', Ou-Xiang Zheng' ${ }^{1}$, Jun-Guo Xin², Hannah H. Chen ${ }^{3}$, John J. Xin ${ }^{4,5}$ \\ ${ }^{I}$ Institute of Criminal Science and Technology, Wenzhou Police Department, Wenzhou 325000, Zhejiang, China. \\ ${ }^{2}$ West China College of Public Health, Sichuan University, Chengdu 610041, Sichuan, China. \\ ${ }^{3}$ Department of Pathology, Loyola University Medical Center, Maywood, IL 60153, USA. \\ ${ }^{4}$ Research and Development Service, Hines VA Hospital, Hines, IL 60141, USA. \\ ${ }^{5}$ Department of Pathology, The University of Chicago Medicine, Chicago, IL 60637, USA.
}

Correspondence to: Dr. John J. Xin, Department of Pathology, The University of Chicago Medicine, 5841 South Maryland Avenue, Rm. TW-020A, MC0006, Chicago, IL 60637, USA. E-mail: neuroimmune@gmail.com; jxin@bsd.uchicago.edu

How to cite this article: Liu JF, Zheng OX, Xin JG, Chen HH, Xin JJ. How are necroptosis, immune dysfunction, and motoneuron death connected in amyotrophic lateral sclerosis? Neuroimmunol Neuroinflammation 2017;4:109-16.

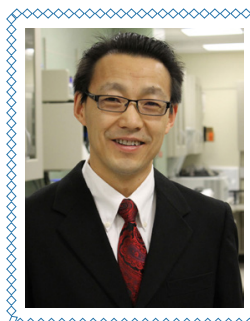

Dr. John J. Xin received his MD degree from West China University of Medical Sciences, and PhD degree from Loyola University Medical Center. He completed postdoctoral training at Loyola and Hines VA Hospital, studying the regulation of immune responses following nerve injury and in neurodegenerative diseases. Since 2012, he has been studying the roles of autoimmunity in human diseases, including neuroinflammatory diseases (MS and ALS), bone marrow failure, leukemia, and transplantation, funded by Muscular Dystrophy Association and Leukemia Research Foundation. Currently, he is working at the University of Chicago and focusing on transplant immunology clinical service and research.

Article history:

Received: 06-03-2017

Accepted: 01-06-2017

Published: 16-06-2017

Key words:

Necroptosis,

Th17,

nerve injury,

amyotrophic lateral sclerosis

\section{ABSTRACT}

Abnormal immune response/inflammation is present in patients of amyotrophic lateral sclerosis (ALS). Autoimmune-related inflammation has been thought to be involved in the pathogenesis of ALS. However, how the abnormal immune responses are initiated, what specific immune cells and how these immune cells are involved in this disease have not been well understood. This is partly owing to two facts of ALS: late diagnosis and chronic nature. The late diagnosis makes it difficult to conclude whether the abnormal immune responses/inflammation is the cause or result of the disease. The chronic nature makes it difficult to determine the best timing for the detection of such autoimmune responses. To resolve these two challenges for research, the authors introduced motor nerve injury (facial nerve axotomy, FNA) into a pre-symptomatic mouse ALS model (8-week-old SOD $1^{G 93 A}$ mice), which induces a readily detectable immune response in a predictable time period (3-14 days). The authors found that pre-symptomatic SOD1 ${ }^{G 93 A}$ mice showed a higher basal level of T cell activation and Th17 cells than WT mice, which can be further increased by FNA. However, why these pro-inflammatory Th lymphocyte c) (1) (2) This is an open access article distributed under the terms of the Creative Commons Attributionnon-commercially, as long as the author is credited and the new creations are licensed under the identical terms.

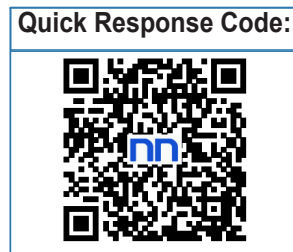


subsets are preferentially elicited in ALS has been elusive. Recently, several studies support that the programmed necrosis (necroptosis), a new type of cell death, is present in ALS. Because necroptosis results in the release of pro-inflammatory stimuli, we speculate that initial motoneuron (MN) necroptosis may be the cause of abnormal immune responses in the development of ALS, and subsequently, inflammation/immune response serve as an amplifier to cause more MN death. Here, the authors reviewed recent studies concerning the type of MN death, the inflammation/immune responses and the research strategies for ALS. With the available evidences from the literature, the authors present a hypothesized working model to indicate the possible connections among necroptosis, immune responses and MN death in the development of ALS and suggest the future studies for searching the potential therapy for ALS.

\section{AMYOTROPHIC LATERAL SCLEROSIS AND RESEARCH MODEL}

Amyotrophic lateral sclerosis (ALS) is a fatal motor neuron (motoneuron, $\mathrm{MN}$ ) disease affecting approximately 30,000 people in the United States and 70,000 people worldwide. ${ }^{[1]}$ Clinically, ALS attacks MNs in the spinal cord, brain stem, and motor cortex, ${ }^{[2]}$ resulting in a loss of muscle tone, generalized weakness, spasticity, paralysis, and consequent fatality. The etiology of ALS is not fully understood, but genetic analysis has led to the identification of approximately 30 gene mutations. ${ }^{[3]}$ The common gene mutations include $\mathrm{Cu} / \mathrm{Zn}$ superoxide dismutase 1 (mSOD1), ${ }^{[4]}$ TDP-43, ${ }^{[5,6]}$ repeat expansion of $C 9$ orf72 gene, ${ }^{[7,8]}$ and many other mutations. ${ }^{[3]}$ The proposed pathogenic mechanisms include protein aggregation and toxicity, abnormal RNA processing, glutamate-mediated excitotoxicity, and neuroinflammation. ${ }^{[1,3]} m S O D 1$ is the first identified gene mutation in familial ALS (present in $20 \%$ of fALS); animal models have been established for this specific variant. ${ }^{[9]} S O D 1^{G 93 A}$ mice carry the human mutant $S O D 1^{G 93 A}$ gene and demonstrate an ALS-like disease course. These mice are currently the most widely used animal model to examine the behavioral, cellular, and molecular aspects of ALS.

\section{MN DEATH TYPES IN ALS}

The pathological hallmark of ALS is progressive loss of MN and motor function. The study for MN death and underlying mechanisms has been the major focus of ALS research in the past decades. Due to the limited availability for human specimen from living ALS patients, most of our knowledge regarding MN death in ALS has been derived from ALS animal model. The previously defined cell death types in ALS include apoptosis, autophagy, and necrosis. Apoptosis has been considered the main type of cell death for a long time. ${ }^{[10-13]}$ In the past decade, several new types of cell death have been defined and characterized: such as parthanatos, inflammasome (NLRP3)-mediated pyroptosis, ferroptosis, pyronecrosis, mitochondrial permeability transition-dependent necrosis. As recently reviewed by Morrice et al.. ${ }^{[14]}$ accumulating evidence indicates that multiple types of cell death may be involved in MN death in ALS. ${ }^{[15,16]}$

\section{NECROPTOSIS AND ITS IMPLICATIONS IN ALS}

Apoptosis is a well defined type of programmed cell death with the involvement of caspase activation. MN apoptosis has been considered as the primary cell death in ALS. Necroptosis is one novel type of cell death and it is also a type of programmed cell death but independent of caspase activation. It is stimulated by TNF and related inflammatory factors such as TRAIL, FasL and ligands for TLRs. ${ }^{[17-20]}$ Activated Caspase-8 induces apoptosis and simultaneously represses necroptosis by cleaving RIP1 and RIP3. ${ }^{[21,22]}$ Inhibition of Caspase-8 can convert apoptosis to RIP1/RIP3mediated necroptosis. ${ }^{[23,24]}$ Necroptosis is considered a pathologic form of cell death which is involved in viral infection, ischemia and reperfusion injury, liver fibrosis and neurodegenerative diseases. ${ }^{[25]}$ Necroptosis can be inhibited by the blocking RIP1/ RIP3 interaction using a small molecule inhibitor of RIP1 kinase, Necrostatin-1 (Nec1) or genetic deletion of RIP3. Rip3 ${ }^{--}$mice develop and grow normally but are resistant to virus-mediated cellular necrosis, ${ }^{[26]}$ ethanol-induced liver injury, ${ }^{[27]}$ and ischemia-reperfusion injury. ${ }^{[2]}$ Recent studies have demonstrated that necroptosis in the nervous system is involved in a variety of neurological disorders, such as multiple sclerosis (MS), ${ }^{[29]}$ traumatic brain injury, ${ }^{[30]}$ and cerebrovascular disease. ${ }^{[31]} \mathrm{Re}$ et al. ${ }^{[32]}$ first revealed that MN necroptosis also occurs in ALS. MN could be induced to undergo necroptosis by astrocytes with mutant $S O D 1^{1693 A}$ or astrocytes from ALS patients. Because intracellular components released during necroptosis stimulate inflammation and immune responses, it is thought that necroptosis contributes to the development/progression of neurodegenerative diseases. Recently, Cirulli et al. ${ }^{[33]}$ compared the whole exome sequences between ALS and control, and found that the non-canonical IKB kinase family TANK-binding kinase 1 (TBK1) was a gene associated with ALS by interacting with ALS-related proteins, optineurin (OPTN) and p62. Furthermore, Ito et al..$^{[34]}$ demonstrated that OPTN inhibited dysmyelination and axonal degeneration through suppressing receptorinteracting kinase 1 (RIPK1) and the downstream 
necroptotic pathway with the involvement of RIPK3, and mixed lineage kinase domain-like protein (MLKL). Taken together, it appears that necroptosis plays a critical role in connecting certain gene mutations with the development of ALS.

While necroptosis itself results in $\mathrm{MN}$ loss directly, it also activates the immune system and results in a secondary inflammatory response. We think that inflammation/immune responses subsequently amplify MN degeneration. During this process, the innate immune responses may act as the first line of reactions to clean up the debris of dead cells with the involvement of vascular reaction, infiltration of neutrophil and macrophage, as well as the proinflammatory cytokine production. Later, the adaptive immune components ( $T$ and $B$ cells) get involved in after certain MN-derived antigens (not clearly defined thus far) are processed and presented to $T$ cells. This notion is supported by our recent finding of the roles of necroptosis in autoimmune bone marrow failure. We found that necroptosis of a small portion of stem cell/ progenitors with gene mutation resulted in autoimmune responses, which caused a rapid depletion of bone marrow cells, which could be prevented by blocking necroptotic pathway via deletion of rip3. ${ }^{[35]}$ We speculate that similar roles of necroptosis may also exist in ALS: a small portion MN that die of necroptosis may cause the autoimmune responses, in which the $\mathrm{MN}$-specific antigens are released and presented to $\mathrm{CD}^{+} \mathrm{T}$ cells. These $\mathrm{T}$ cells may preferentially develop into pro-inflammatory subsets and further amplify the inflammation/immune responses, and cause more MN death. Below, we continue discussing the dysfunction of immune system that has been identified in ALS.

\section{IMMUNE DYSFUNCTION IN ALS}

In the past few decades, accumulating evidence indicates that immune system abnormalities and inflammation contribute to the development of ALS. ${ }^{[36]}$ Macrophage, $\mathrm{T}$ cell, and mast cell infiltration have been observed in ALS CNS tissues. ${ }^{[37]}$ Because of the large amount of inflammatory cells infiltrating the CNS during disease progression, it was postulated that, similar to MS, ALS may also be in part an autoimmune disease. ${ }^{[38,39]}$ Several anti-inflammatory and/or immuno-compromising drugs also support the contribution of inflammatory components in the pathogenesis of ALS. While the gene mutation and the resultant protein in MN may mediate a direct toxic effect for neuron, dysfunctional microglial cells and astrocytes with gene mutations may also contribute to neuronal death. ${ }^{[40-44]}$
While the glial cell-mediated neurotoxicity is relatively well documented, elucidating how other immune cells are involved in regulation of glial cell function and $\mathrm{MN}$ death remains a challenging project. First, the immune regulation in ALS appears to be more complicated than our understanding for it on the basis of the knowledge acquired from other conditions. For examples, it has been well known that NF- $\kappa B$ is a factor that mediated the signals of most inflammatory factors. ${ }^{[45]}$ TNF- $\alpha$, a classical inflammatory cytokine that activates NF- $\kappa B$ and significantly increased in ALS mice and patients. TNF- $\alpha$ is one of the best known factors mediating necroptosis, ${ }^{[17,18,46]}$ but knockout of TNF- $\alpha$ in SOD1 ${ }^{693 A}$ mice did not block ALS disease in SOD1 ${ }^{G 93 A}$ mice. ${ }^{[47]}$ In contrast, inhibition of NF-kB can slow down disease progression, ${ }^{[47]}$ suggesting that other inflammatory cytokines, other than TNF- $\alpha$, might also activate NF$\kappa B$ and contribute to $M N$ death. Second, the transgenic animal model of ALS is our current major tool to study this disease. However, findings in animal model may not be applicable for patient. For example, inhibition of microglial activation with Minocycline significantly delayed the onset of motor neuron degeneration and slowed down disease progression in ALS mice, ${ }^{[48]}$ its effect in ALS patients remains in question. ${ }^{[49]}$ Furthermore, the mutual inhibitory effect among immune components, such as the counteracting functions between Th17 and Treg cells, as well as between Th1 and Th2 cells (this topic will be further discussed in the below section of ENVIRONMENTDEPENDENT FUNCTION OF CD4 ${ }^{+} \mathrm{T}$ CELLS IN ALS), make it more complicated to use a general immunosuppressant to achieve therapeutic effect. For example, Sulindac, a nonsteroidal anti-inflammatory drug (NSAID) and inhibitor of pro-inflammatory COX1 \& COX-2, significantly increases the survival, and preservation of spinal cord motoneurons. ${ }^{[50]}$ However, a large number of immunosuppressive approaches, such as cyclosporine, cyclophosphamide, and total lymphoid removal failed to benefit ALS patients. ${ }^{[51,52]}$ The previously published data for both beneficial and detrimental effects of immune components imply that immune system has dual roles in ALS.

\section{NECROPTOSIS AND IMMUNE DYSFUNCTION}

Recently, $\operatorname{Re}$ et al. ${ }^{[32]}$ and Ito et $a{ }^{\left[{ }^{[34]}\right.}$ found that necroptosis may be involved in the $\mathrm{MN}$ death. This finding provides an important connection between neurodegeneration and previously observed abnormal inflammation/immune response in ALS. Unlike apoptosis that does not elicit immune responses, necroptosis results in the releases of $\mathrm{MN}$ specific antigens (MN-Ag) and other pro-inflammatory stimuli, which are also called Damage-Associated 
Molecular Patterns (DAMPs), such as mitochondria, ATP and alarmins. ${ }^{[46]}$ In addition, Frakes et al. ${ }^{[45]}$ found that NF-kB-activation determines the proinflammatory phenotype of microglial cells, which in turn contributes to neuronal death. Two questions concerning how immune cells are involved in the regulation of glial cell function remains to be answered. First, what are the specific autoimmune cells involved in the interaction of glial cell and MN? and second, how should we dissect the dual functions of immune system in ALS? As aforementioned, the general immunosuppressants, which have inhibitory effects on overall immune system, appear to have minimal therapeutic effect, presumably due to the simultaneous inhibition of immune components that have beneficial effects. ${ }^{[51,52]}$ Consistent with this notion, knockout of $\mathrm{CD}^{+} \mathrm{T}$ cells in SOD1 ${ }^{\mathrm{G} 93 A}$ mice resulted in exacerbation of ALS-like symptoms and a decreased life span. ${ }^{[53,54]}$ Collectively, it appears that $\mathrm{CD}^{+}{ }^{+} \mathrm{T}$ cell-mediated regulation determines the direction and nature of immune responses in ALS, and an ideal immune-based therapy for ALS should be able to inhibit the "detrimental" effects of immune cell without simultaneously comprising the "beneficial" functions. Therefore, it is necessary to identify the specific subsets of immune cells and to elucidate how they are involved in the pathogenesis of ALS.

\section{ENVIRONMENT-DEPENDENT FUNCTION OF $\mathrm{CD4}^{+} \mathrm{T}$ CELLS IN ALS}

In ALS patients, it was found that the total number of lymphocyte and naïve $C D 4^{+} T$ cells $\left(C D 45 R A^{+}\right)$was decreased in late-stage and there was a significant $\mathrm{CD}^{+} \mathrm{T}$ cell infiltration in the spinal cord and brain. In addition, $T$ cells were present in ALS patient cerebrospinal fluid with a predominant Th1 phenotype. $\mathrm{CD}^{+} \mathrm{T}$ cells have different subsets with distinct functions, which are determined by the cytokines they produce. IFN- $\gamma$-producing Th1 and IL-17-producing Th17 (both produce TNF- $\alpha$ ) promote inflammation; In contrast, IL-4 producing Th2 and IL-10-producing T regulatory cell (Treg) inhibit inflammation. Other and our groups have showed that $\mathrm{CD} 4^{+} \mathrm{T}$ cells mediate anti-inflammatory effect after nerve injury as well as in ALS disease; however it is in context- and subsetdependent manner. ${ }^{[53-56]}$ It is generally thought that beneficial effects of $\mathrm{CD}^{+} \mathrm{T}$ cells are mainly mediated by its anti-neuroinflammatory subsets, such as Treg and Th2 cells ${ }^{[56,57]}$ and that detrimental effects are mediated by pro-inflammatory $\mathrm{CD}^{+} \mathrm{T}$ subsets, such asTh1 and Th17 cells. The differential development of $\mathrm{CD}^{+} \mathrm{T}$ subset is determined by both $\mathrm{CD} 4^{+} \mathrm{T}$ cells and their cytokine environment. To determine whether the "detrimental" Th cells development in ALS was due to the defect of $\mathrm{CD} 4^{+} \mathrm{T}$ cells with $S O D 1^{\text {G93A }}$ mutation or due to the special cytokine microenvironment in $S O D 1^{\mathrm{G} 93 \mathrm{~A}}$ mice, we isolated $\mathrm{CD}^{+} \mathrm{T}$ cells in the spleen from WT and SOD1G93A mice and adoptively transferred to immune-deficient mice Rag2 ${ }^{-1}$ ("normal" microenvironment) or SOD $1^{\text {G93A }}$ (inflammatory environment) and studied if they can support motoneuron survival after facial nerve axotomy (FNA). Facial motoneuron (FMN) survival post 4-week operation in each group were counted and calculated as percentage of FMN number on axotomized side compared to uninjured side. Rag2 $2^{--}$mice lacks B and T cells and FNA induced a significant FMN loss, which could be prevented by adoptive transfer of either WT whole splenocytes or purified CD4 $4^{+} \mathrm{T}$ cell. SOD1G93A mice also showed a significant FMN loss than WT mice after FNA. However, such loss could only be rescued by WT whole splenocytes but not purified WT CD4 ${ }^{+} \mathrm{T}$ cells, suggesting that microenvironment determines the beneficial function of $\mathrm{CD} 4^{+} \mathrm{T}$ cells and that microenrivronment in SOD1 ${ }^{\text {G93A }}$ mouse does not support the development of beneficial $C D 4^{+} T$ subsets. Therefore, we compared the FNA-induced FMN loss between Rag2 $2^{--}$mice that received SOD ${ }^{\text {G93A }}$ whole splenocytes and Rag2 $2^{-/}$mice that received purified SOD $1^{\text {G93A }} \mathrm{CD}^{+} \mathrm{T}$ cells. As expected, we found that the purified SOD $1^{\text {G93A }} \mathrm{CD} 4^{+} \mathrm{T}$ cells still could support FMN survival but whole splenocytes did not. ${ }^{[58]}$ Collectively, these data suggest that microenvironment in SOD $1^{\text {G93A }}$ mice might have a condition that primes $\mathrm{CD} 4^{+} \mathrm{T}$ cell into detrimental subsets.

\section{TH17 CELLS, NERVE INJURY AND ALS}

Th17 cells are a subset of $\mathrm{CD} 4^{+} \mathrm{T}$ cells that play an important role in promoting inflammation, including angiogenesis and the recruitment of multiple types of immune cells to injury sites. ${ }^{[59]}$ Th17 cells are crucial for the development of certain autoimmune diseases, exhibiting neurodestructive effects in neuroinflammatory diseases. ${ }^{[60]}$ In ALS patients, elevated IL-17 and Th17-related cytokines (IL-6, TNF- $\alpha$, IL-1 and IL-23) ${ }^{[61-63]}$ have been observed. However, the contribution of Th17 cells in promoting ALS development has not been established yet because of two challenges: late diagnosis and chronic disease. Late diagnosis makes it difficult to conclude whether the abnormal immune responses/ inflammation is the cause or result of the disease. The chronic nature of ALS makes it difficult to determine the best timing for the detection of such autoimmune responses. To resolve these two challenges, we have applied motor nerve injury (facial nerve axotomy, FNA) into a pre-symptomatic mouse ALS model (8-week old $\left.S O D 1^{G 93 A}\right)$ mice, which introduces nerve injury and 
MN death by surgery in an acute manner. Because of the chronic nature of ALS disease, no peak time of immune response has been defined previously. Without a peak time, it is challenging to characterize the subtle change of immune parameters. Our previous studies for immune responses following nerve injury indicated that $\mathrm{CD} 4^{+} \mathrm{T}$ cell responses can be detected by intracellular staining for the cytokine production from the day 3 to day 14 post-axotomy. ${ }^{[64]}$ Such axotomy model allows us to design the best measuring time point for the research and can be utilized as a model tool for further study of immune response in ALS mouse.

While more and more genetic risks (gene mutation) for ALS are being defined, the environmental risk factors for ALS are relatively poorly defined. One defined environmental risk is related to occupations, such as military veterans, varsity athletes, and professional football players. ${ }^{[65-67]}$ Because these populations share the same risk which distinguished them from other populations, that is, they have increased chance of motor nerve injury, we reasoned that motor nerve injury might trigger the development and/or accelerate the progression of ALS. Therefore, we conducted a study to determine the immune responses after nerve injury in mouse ALS model. ${ }^{[68]}$ Without axotomy, SOD $1^{\text {G93A }}$ mice showed a higher level of Th17 cells in term of both frequency and absolute number, when compared to WT mice. Th17 cell frequency and total number can be further increased by nerve injury. We speculate that nerve injury might promote autoimmune responses, especially in those individuals with a genetic susceptibility. Collectively, these data suggest that motor neuron death, autoimmune responses, and disease progression may mutually promote each other.

Regarding further study for the roles of Th17 cells in mouse ALS model, the FNA in ALS mice may be a useful tool. First, FNA is a well-established paradigm for the study of MN survival, functional recovery and immune response after nerve injury. ${ }^{[69]}$ After FNA, neuronal death occurs by two potential mechanisms: necrosis directly resulting from the disruption of cell integrity, and apoptosis resulting from the stimulation of excitatory neuronal transmitters and oxidative stress mediators. These death mechanisms have been also proposed for the MN death in ALS. ${ }^{[1]}$ Additionally, ALS MN degeneration exhibits axonal "die-back" pathology, in which degeneration occurs at the neuromuscular junction causing the axons to withdraw from target muscle in a "die-back" manner to the cell bodies in the CNS. This process is very similar to axotomy-induced axonal damage and neuronal degeneration. ${ }^{[70,71]}$ Furthermore, FNA can induce $\mathrm{CD}^{+} \mathrm{T}$ cell responses in both WT and SOD $1^{\text {G93A }}$ mice. Lastly and importantly, as we mentioned in the earlier section of "TH17 CELLS, NERVE INJURY AND ALS", FNA can "artificially" create an acute "onset" of neurodegeneration and provide a predictable time frame during which to study the acute immune response in mice. ${ }^{[64,72]}$ Using this model, we found that FNA induced greater and prolonged immune responses in draining lymph nodes of $S O D 1^{G 93 A}$ mice than WT mice, ${ }^{[68]}$ suggesting Th17 cell could be a potential therapeutic target for ALS treatment.

\section{A HYPOTHESIZED WORKING MODEL OF ALS PATHOGENESIS AND FUTURE DIRECTIONS}

Based on the literature and our data, we reason that there is a cascade in the ALS disease development/ progression. As illustrated in Figure 1, we hypothesize that motor nerve injury triggers MN necroptosis (1), which induces Th17 cell responses (2), and Th17 cellmediated autoimmune reactions (3), leading to more $\mathrm{MN}$ death and promoting rapid disease progression. Specifically, environmental insult including physical damage or Wallerian-like degeneration, such as physical injury, toxin, radiation and/or intrinsic genetic defect cause the necroptosis of a small portion of MNs. During necroptosis, dying MNs release MNspecific antigens (MN-Ag) as well as pro-inflammatory stimuli, such as ATP, mitochondria, and alarmins; ${ }^{[18]}$ (2) $\mathrm{MN}-\mathrm{Ag}$ is processed and presented to naive $\mathrm{T}$ cells in draining lymph node, where naïve $\mathrm{CD}^{+} \mathrm{T}$ cells are primed into a Th17 cell phenotype in the presence of Th17-promoting cytokines [TGF- $\beta$, IL-6, IL-21 (murine) and IL-1 (human) and IL-23]; 3 MNAg-specific Th17 cells are potentially recruited into the CNS, where they further promote more MN death through two possible mechanisms: (1) amplifying non-

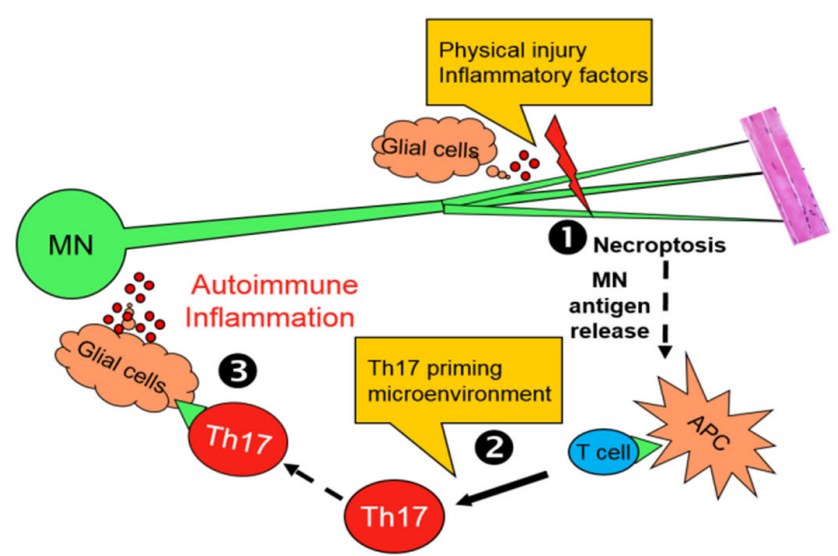

Figure 1: A working model of MN injury, necroptosis, and Th17 cell responses, and their roles in the development and progression of amyotrophic lateral sclerosis. MN: motoneuron; APC: antigenpresenting cell 
specific inflammation by enhancing angiogenesis and recruiting neutrophil and other innate immune cells and cause stand-by damage to MNs; (2) interacting with infiltrating macrophage and/or glial cells (microglial cells and astrocytes) and initiating an autoimmune response specifically attacking $\mathrm{MN}$. We think these two mechanisms may be present at the same time and synergically cause extensive $\mathrm{MN}$ necroptosis in a short period and lead to rapid disease progression after disease onset.

Although the overall model is supported by the published data, details in each step are still unclear. First, the specific MN antigens involved in ALS have not been clearly defined yet. Second, how the Th17promoting cytokines are preferentially up-regulated in ALS is not clear. Third, whether pro-inflammatory cells are the cause or the results of $\mathrm{MN}$ death remains to be elucidated. Fourth, it is unknown whether the immune cells directly act on MN or indirectly sensitize the $\mathrm{MN}$ body to be more vulnerable to insults. Last, regarding whether the necroptotic pathway is a therapeutic target, Ito et al. ${ }^{\left[{ }^{[3]}\right.}$ showed that blocking necroptosis through knockout of Rip3 or using Rip1 inhibitor (Nec-1s) delayed the disease onset for approximately 5 days, but whether blocking necroptosis can slow down the disease progression after its onset remain elusive. It is suggested that necroptosis may play a role only in the initiation stage. After the onset, the disease progression may mainly mediated by the immune dysfunction, and the immune system should be concurrently targeted during ALS treatment.

\section{Authors' contributions}

Performed the literature search and drafted the manuscript: J.F. Liu, O.X. Zheng, J.G. Xin

Revised and edited the manuscript: H.H. Chen, J.J. Xin

Designed and supervised this study: J.J. Xin

\section{Acknowledgments}

We thank the productive collaboration with Drs. Jiwang Zhang, Peter Breslin, Evan B. Stubbs, Eilleen M. Foecking, Virginia M. Sanders, Kathrine J. Jones, and Derek A. Wainwright.

\section{Financial support and sponsorship}

This work was supported by a grant from Muscular Dystrophy Association (MDA202906). John J. Xin is also supported by the Leukemia Research Foundation New Investigator Award (8th Annual George Richard Memorial Grant).

\section{Conflicts of interest}

There are no conflicts of interest.

\section{Patient consent}

Not applicable.

\section{Ethics approval \\ Not applicable.}

\section{REFERENCES}

1. Bruijn LI, Miller TM, Cleveland DW. Unraveling the mechanisms involved in motor neuron degeneration in ALS. Annu Rev Neurosci 2004;27:723-49.

2. Mendonça DM, Chimelli L, Martinez AM. Martinez. Quantitative evidence for neurofilament heavy subunit aggregation in motor neurons of spinal cords of patients with amyotrophic lateral sclerosis. Braz J Med Biol Res 2005;38:925-33.

3. Sreedharan J, Brown RH Jr. Amyotrophic lateral sclerosis: problems and prospects. Ann Neurol 2013;74:309-16.

4. Aoki M, Ogasawara M, Matsubara Y, Narisawa K, Nakamura S, Itoyama Y, Abe K. Mild ALS in Japan associated with novel SOD mutation. Nat Genet 1993;5:323-4.

5. Neumann M, Sampathu DM, Kwong LK, Truax AC, Micsenyi MC, Chou TT, Bruce J, Schuck T, Grossman M, Clark CM, McCluskey LF, Miller BL, Masliah E, Mackenzie IR, Feldman H, Feiden W, Kretzschmar HA, Trojanowski JQ, Lee VM. Ubiquitinated TDP-43 in frontotemporal lobar degeneration and amyotrophic lateral sclerosis. Science 2006;314:130-3.

6. Sreedharan J, Blair IP, Tripathi VB, Hu X, Vance C, Rogelj B, Ackerley S, Durnall JC, Williams KL, Buratti E, Baralle F, de Belleroche J, Mitchell JD, Leigh PN, Al-Chalabi A, Miller CC, Nicholson G, Shaw CE. TDP-43 mutations in familial and sporadic amyotrophic lateral sclerosis. Science 2008;319:1668-72.

7. Morita M, Al-Chalabi A, Andersen PM, Hosler B, Sapp P, Englund E, Mitchell JE, Habgood JJ, de Belleroche J, Xi J, Jongjaroenprasert W, Horvitz HR, Gunnarsson LG, Brown RH Jr. A locus on chromosome $9 \mathrm{p}$ confers susceptibility to ALS and frontotemporal dementia. Neurology 2006;66:839-44.

8. Vance C, Al-Chalabi A, Ruddy D, Smith BN, Hu X, Sreedharan J, Siddique T, Schelhaas HJ, Kusters B, Troost D, Baas F, de Jong V, Shaw CE. Familial amyotrophic lateral sclerosis with frontotemporal dementia is linked to a locus on chromosome 9p13.2-21.3. Brain 2006;129:868-76.

9. Gurney ME, Pu H, Chiu AY, Dal Canto MC, Polchow CY, Alexander DD, Caliendo J, Hentati A, Kwon YW, Deng HX. Motor neuron degeneration in mice that express a human $\mathrm{Cu}, \mathrm{Zn}$ superoxide dismutase mutation. Science 1994;264:1772-5.

10. Sathasivam S, Shaw PJ. Apoptosis in amyotrophic lateral sclerosis -what is the evidence? Lancet Neurol 2005;4:500-9.

11. Raoul C, Estévez AG, Nishimune H, Cleveland DW, deLapeyrière O, Henderson CE, Haase G, Pettmann B. Motoneuron death triggered by a specific pathway downstream of Fas. potentiation by ALS-linked SOD1 mutations. Neuron 2002;35:1067-83.

12. Martin LJ. Neuronal death in amyotrophic lateral sclerosis is apoptosis: possible contribution of a programmed cell death mechanism. $J$ Neuropathol Exp Neurol 1999;58:459-71.

13. Li M, Ona VO, Guégan C, Chen M, Jackson-Lewis V, Andrews LJ, Olszewski AJ, Stieg PE, Lee JP, Przedborski S, Friedlander RM. Functional role of caspase-1 and caspase-3 in an ALS transgenic mouse model. Science 2000;288:335-9.

14. Morrice JR, Gregory-Evans CY, Shaw CA. Necroptosis in amyotrophic lateral sclerosis and other neurological disorders. Biochim Biophys Acta 2017;1863:347-53.

15. Zhao W, Beers DR, Bell S, Wang J, Wen S, Baloh RH, Appel SH. 
TDP-43 activates microglia through NF-kappaB and NLRP3 inflammasome. Exp Neurol 2015;273:24-35.

16. Kadhim H, Deltenre P, Martin JJ, Sébire G. In-situ expression of Interleukin-18 and associated mediators in the human brain of sALS patients: hypothesis for a role for immune-inflammatory mechanisms. Med Hypotheses 2016;86:14-7.

17. Kaiser WJ, Upton JW, Long AB, Livingston-Rosanoff D, Daley-Bauer LP, Hakem R, Caspary T, Mocarski ES. RIP3 mediates the embryonic lethality of caspase-8-deficient mice. Nature 2011;471:368-72.

18. Galluzzi L, Vanden Berghe T, Vanlangenakker N, Buettner S, Eisenberg T, Vandenabeele P, Madeo F, Kroemer G. Programmed necrosis from molecules to health and disease. Int Rev Cell Mol Biol 2011;289:1-35.

19. Xiao Y, Li H, Zhang J, Volk A, Zhang S, Wei W, Zhang S, Breslin $\mathrm{P}$, Zhang J. TNF- $\alpha /$ Fas-RIP-1-induced cell death signaling separates murine hematopoietic stem cells/progenitors into 2 distinct populations. Blood 2011;118:6057-67.

20. Osborn SL, Diehl G, Han SJ, Xue L, Kurd N, Hsieh K, Cado D, Robey EA, Winoto A. Fas-associated death domain (FADD) is a negative regulator of T-cell receptor-mediated necroptosis. Proc Natl Acad Sci U S A 2010;107:13034-9.

21. Zhang DW, Shao J, Lin J, Zhang N, Lu BJ, Lin SC, Dong MQ, Han J. RIP3, an energy metabolism regulator that switches TNF-induced cell death from apoptosis to necrosis. Science 2009;325:332-6.

22. Tenev T, Bianchi K, Darding M, Broemer M, Langlais C, Wallberg F, Zachariou A, Lopez J, MacFarlane M, Cain K, Meier P. The Ripoptosome, a signaling platform that assembles in response to genotoxic stress and loss of IAPs. Mol Cell 2011;43:432-48.

23. Feoktistova M, Geserick P, Kellert B, Dimitrova DP, Langlais C, Hupe M, Cain K, MacFarlane M, Häcker G, Leverkus M. cIAPs block Ripoptosome formation, a RIP1/caspase- 8 containing intracellular cell death complex differentially regulated by cFLIP isoforms. Mol Cell 2011;43:449-63.

24. Vandenabeele P, Melino G. The flick of a switch: which death program to choose? Cell Death Differ 2012;19:1093-5.

25. Christofferson DE, Yuan J. Necroptosis as an alternative form of programmed cell death. Curr Opin Cell Biol 2010;22:263-8.

26. Upton JW, Kaiser WJ, Mocarski ES. DAI/ZBP1/DLM-1 complexes with RIP3 to mediate virus-induced programmed necrosis that is targeted by murine cytomegalovirus vIRA. Cell Host Microbe 2012;11:290-7.

27. Roychowdhury S, McMullen MR, Pisano SG, Liu X, Nagy LE. Absence of receptor interacting protein kinase 3 prevents ethanolinduced liver injury. Hepatology 2013;57:1773-83.

28. Linkermann A, Bräsen JH, Darding M, Jin MK, Sanz AB, Heller JO, De Zen F, Weinlich R, Ortiz A, Walczak H, Weinberg JM, Green DR, Kunzendorf U, Krautwald S. Two independent pathways of regulated necrosis mediate ischemia-reperfusion injury. Proc Natl Acad Sci US A 2013;110:12024-9.

29. Ofengeim D, Ito Y, Najafov A, Zhang Y, Shan B, DeWitt JP, Ye J, Zhang X, Chang A, Vakifahmetoglu-Norberg H, Geng J, Py B, Zhou W, Amin P, Berlink Lima J, Qi C, Yu Q, Trapp B, Yuan J. Activation of necroptosis in multiple sclerosis. Cell Rep 2015;10:1836-49.

30. You Z, Savitz SI, Yang J, Degterev A, Yuan J, Cuny GD, Moskowitz MA, Whalen MJ. Necrostatin-1 reduces histopathology and improves functional outcome after controlled cortical impact in mice. $J$ Cereb Blood Flow Metab 2008;28:1564-73.

31. Han W, Xie J, Li L, Liu Z, Hu X. Necrostatin-1 reverts shikonininduced necroptosis to apoptosis. Apoptosis 2009;14:674-86.

32. Re DB, Le Verche V, Yu C, Amoroso MW, Politi KA, Phani S, Ikiz B, Hoffmann L, Koolen M, Nagata T, Papadimitriou D, Nagy P, Mitsumoto H, Kariya S, Wichterle H, Henderson CE, Przedborski S. Necroptosis drives motor neuron death in models of both sporadic and familial ALS. Neuron 2014;81:1001-8.

33. Cirulli ET, Lasseigne BN, Petrovski S, Sapp PC, Dion PA, Leblond CS, Couthouis J, Lu YF, Wang Q, Krueger BJ, Ren Z, Keebler J, Han Y, Levy SE, Boone BE, Wimbish JR, Waite LL, Jones AL, Carulli JP, Day-Williams AG, Staropoli JF, Xin WW, Chesi A, Raphael AR, McKenna-Yasek D, Cady J, Vianney de Jong JM, Kenna KP, Smith BN, Topp S, Miller J, Gkazi A; FALS Sequencing Consortium, AlChalabi A, van den Berg LH, Veldink J, Silani V, Ticozzi N, Shaw CE, Baloh RH, Appel S, Simpson E, Lagier-Tourenne C, Pulst SM, Gibson S, Trojanowski JQ, Elman L, McCluskey L, Grossman M, Shneider NA, Chung WK, Ravits JM, Glass JD, Sims KB, Van Deerlin VM, Maniatis T, Hayes SD, Ordureau A, Swarup S, Landers J, Baas F, Allen AS, Bedlack RS, Harper JW, Gitler AD, Rouleau GA, Brown R, Harms MB, Cooper GM, Harris T,Myers RM, Goldstein DB. Exome sequencing in amyotrophic lateral sclerosis identifies risk genes and pathways. Science 2015;347:1436-41.

34. Ito Y, Ofengeim D, Najafov A, Das S, Saberi S, Li Y, Hitomi J, Zhu H, Chen H, Mayo L, Geng J, Amin P, DeWitt JP, Mookhtiar AK, Florez M, Ouchida AT, Fan JB, Pasparakis M, Kelliher MA, Ravits J, Yuan J. RIPK1 mediates axonal degeneration by promoting inflammation and necroptosis in ALS. Science 2016;353:603-8.

35. Xin J, Breslin P, Wei W, Li J, Gutierrez R, Cannova J, Ni A, Ng G, Schmidt R, Chen H, Parini V, Kuo PC, Kini AR, Stiff P, Zhu J, Zhang J. Necroptosis in spontaneously-mutated hematopoietic cells induces autoimmune bone marrow failure in mice. Haematologica 2017;102:295-307.

36. Bowerman M, Vincent T, Scamps F, Perrin FE, Camu W, Raoul C. Neuroimmunity dynamics and the development of therapeutic strategies for amyotrophic lateral sclerosis. Front Cell Neurosci 2013;7:214.

37. Rodrigues MC, Voltarelli JC, Sanberg PR, Borlongan CV, GarbuzovaDavis S. Immunological aspects in amyotrophic lateral sclerosis. Transl Stroke Res 2012;3:331-40.

38. Appel SH, Smith RG, Engelhardt JI, Stefani E. Evidence for autoimmunity in amyotrophic lateral sclerosis. $J$ Neurol Sci 1993;118:169-74.

39. Pagani MR, Gonzalez LE, Uchitel OD. Autoimmunity in amyotrophic lateral sclerosis: past and present. Neurol Res Int 2011;2011:497080.

40. Di Giorgio FP, Boulting GL, Bobrowicz S, Eggan KC. Human embryonic stem cell-derived motor neurons are sensitive to the toxic effect of glial cells carrying an ALS-causing mutation. Cell Stem Cell 2008;3:637-48.

41. Di Giorgio FP, Carrasco MA, Siao MC, Maniatis T, Eggan K. Noncell autonomous effect of glia on motor neurons in an embryonic stem cell-based ALS model. Nat Neurosci 2007;10:608-14.

42. Haidet-Phillips AM, Hester ME, Miranda CJ, Meyer K, Braun L, Frakes A, Song S, Likhite S, Murtha MJ, Foust KD, Rao M, Eagle A, Kammesheidt A, Christensen A, Mendell JR, Burghes AH, Kaspar BK. Astrocytes from familial and sporadic ALS patients are toxic to motor neurons. Nat Biotechnol 2011;29:824-8.

43. Marchetto MC, Muotri AR, Mu Y, Smith AM, Cezar GG, Gage FH. Non-cell-autonomous effect of human SOD1 G37R astrocytes on motor neurons derived from human embryonic stem cells. Cell Stem Cell 2008;3:649-57.

44. Xiao Q, Zhao W, Beers DR, Yen AA, Xie W, Henkel JS, Appel SH Mutant SOD1(G93A) microglia are more neurotoxic relative to wildtype microglia. $J$ Neurochem 2007;102:2008-19.

45. Frakes AE, Ferraiuolo L, Haidet-Phillips AM, Schmelzer L, Braun L, Miranda CJ, Ladner KJ, Bevan AK, Foust KD, Godbout JP, Popovich PG, Guttridge DC, Kaspar BK. Microglia induce motor neuron death via the classical NF- $\mathrm{B}$ pathway in amyotrophic lateral sclerosis. Neuron 2014;81:1009-23.

46. Kaczmarek A, Vandenabeele P, Krysko DV. Necroptosis: the release of 
damage-associated molecular patterns and its physiological relevance. Immunity 2013;38:209-23.

47. Gowing G, Dequen F, Soucy G, Julien JP. Absence of tumor necrosis factor-alpha does not affect motor neuron disease caused by superoxide dismutase 1 mutations. J Neurosci 2006;26:11397-402.

48. Kriz J, Nguyen MD, Julien JP. Minocycline slows disease progression in a mouse model of amyotrophic lateral sclerosis. Neurobiol Dis 2002;10:268-78.

49. Gordon PH, Moore DH, Miller RG, Florence JM, Verheijde JL, Doorish C, Hilton JF, Spitalny GM, MacArthur RB, Mitsumoto H, Neville HE, Boylan K, Mozaffar T, Belsh JM, Ravits J, Bedlack RS, Graves MC, McCluskey LF, Barohn RJ, Tandan R; Western ALS Study Group. Efficacy of minocycline in patients with amyotrophic lateral sclerosis: a phase III randomised trial. Lancet Neurol 2007;6:1045-53.

50. Kiaei M, Kipiani K, Petri S, Choi DK, Chen J, Calingasan NY, Beal MF. Integrative role of cPLA with COX-2 and the effect of nonsteriodal anti-inflammatory drugs in a transgenic mouse model of amyotrophic lateral sclerosis. J Neurochem 2005;93:403-11.

51. Brown RH Jr, Hauser SL, Harrington H, Weiner HL. Failure of immunosuppression with a ten- to 14-day course of high-dose intravenous cyclophosphamide to alter the progression of amyotrophic lateral sclerosis. Arch Neurol 1986;43:383-4.

52. Drachman DB, Chaudhry V, Cornblath D, Kuncl RW, Pestronk A, Clawson L, Mellits ED, Quaskey S, Quinn T, Calkins A. Trial of immunosuppression in amyotrophic lateral sclerosis using total lymphoid irradiation. Ann Neurol 1994;35:142-50.

53. Banerjee R, Mosley RL, Reynolds AD, Dhar A, Jackson-Lewis V, Gordon PH, Przedborski S, Gendelman HE. Adaptive immune neuroprotection in G93A-SOD1 amyotrophic lateral sclerosis mice. PLoS One 2008;3:e2740.

54. Chiu IM, Chen A, Zheng Y, Kosaras B, Tsiftsoglou SA, Vartanian TK, Brown RH Jr, Carroll MC. T lymphocytes potentiate endogenous neuroprotective inflammation in a mouse model of ALS. Proc Natl Acad Sci U S A 2008;105:17913-8.

55. Deboy CA, Xin J, Byram SC, Serpe CJ, Sanders VM, Jones KJ. Immune-mediated neuroprotection of axotomized mouse facial motoneurons is dependent on the IL-4/STAT6 signaling pathway in CD4(+) T cells. Exp Neurol 2006;201:212-24.

56. Henkel JS, Beers DR, Wen S, Rivera AL, Toennis KM, Appel JE, Zhao W, Moore DH, Powell SZ, Appel SH. Regulatory T-lymphocytes mediate amyotrophic lateral sclerosis progression and survival. EMBO Mol Med 2013;5:64-79.

57. Zhao W, Beers DR, Liao B, Henkel JS, Appel SH. Regulatory T lymphocytes from ALS mice suppress microglia and effector $\mathrm{T}$ lymphocytes through different cytokine-mediated mechanisms. Neurobiol Dis 2012;48:418-28.

58. Mesnard-Hoaglin NA, Xin J, Haulcomb MM, Batka RJ, Sanders VM, Jones KJ. SOD1(G93A) transgenic mouse CD4(+) T cells mediate neuroprotection after facial nerve axotomy when removed from a suppressive peripheral microenvironment. Brain Behav Immun 2014;40:55-60.
59. Korn T, Bettelli E, Oukka M, Kuchroo VK. IL-17 and Th17 Cells. Annu Rev Immunol 2009;27:485-517.

60. Maddur MS, Miossec P, Kaveri SV, Bayry J. Th17 cells: biology, pathogenesis of autoimmune and inflammatory diseases, and therapeutic strategies. Am J Pathol 2012;181:8-18.

61. Rentzos M, Rombos A, Nikolaou C, Zoga M, Zouvelou V, Dimitrakopoulos A, Alexakis T, Tsoutsou A, Samakovli A, Michalopoulou M, Evdokimidis J. Interleukin-17 and interleukin-23 are elevated in serum and cerebrospinal fluid of patients with ALS: a reflection of Th17 cells activation? Acta Neurol Scand 2010;122:425-9.

62. Fiala M, Chattopadhay M, La Cava A, Tse E, Liu G, Lourenco E, Eskin A, Liu PT, Magpantay L, Tse S, Mahanian M, Weitzman R, Tong J, Nguyen C, Cho T, Koo P, Sayre J, Martinez-Maza O, Rosenthal MJ, Wiedau-Pazos M. IL-17A is increased in the serum and in spinal cord CD8 and mast cells of ALS patients. J Neuroinflammation 2010;7:76.

63. Moreau C, Devos D, Brunaud-Danel V, Defebvre L, Perez T, Destée A, Tonnel AB, Lassalle P, Just N. Elevated IL-6 and TNF-alpha levels in patients with ALS: inflammation or hypoxia? Neurology 2005;65:1958-60.

64. Xin J, Wainwright DA, Serpe CJ, Sanders VM, Jones KJ. Phenotype of CD4+ $\mathrm{T}$ cell subsets that develop following mouse facial nerve axotomy. Brain Behav Immun 2008;22:528-37.

65. Horner RD, Kamins KG, Feussner JR, Grambow SC, Hoff-Lindquist J, Harati Y, Mitsumoto H, Pascuzzi R, Spencer PS, Tim R, Howard D, Smith TC, Ryan MA, Coffman CJ, Kasarskis EJ. Occurrence of amyotrophic lateral sclerosis among Gulf War veterans. Neurology 2003;61:742-9.

66. Scarmeas N, Shih T, Stern Y, Ottman R, Rowland LP. Premorbid weight, body mass, and varsity athletics in ALS. Neurology 2002;59:773-5.

67. Chiò A, Benzi G, Dossena M, Mutani R, Mora G. Severely increased risk of amyotrophic lateral sclerosis among Italian professional football players. Brain 2005;128:472-6.

68. Ni A, Yang T, Mesnard-Hoaglin NA, Gutierrez R, Stubbs EB Jr, McGuire SO, Sanders VM, Jones KJ, Foecking EM, Xin J. Th17 cell response in SOD1G93A mice following motor nerve injury. Mediators Inflamm 2016;2016:6131234.

69. Moran LB, Graeber MB. The facial nerve axotomy model. Brain Res Brain Res Rev 2004;44:154-78.

70. Frey D, Schneider C, Xu L, Borg J, Spooren W, Caroni P. Early and selective loss of neuromuscular synapse subtypes with low sprouting competence in motoneuron diseases. J Neurosci 2000;20:2534-42.

71. Fischer LR, Culver DG, Tennant P, Davis AA, Wang M, CastellanoSanchez A, Khan J, Polak MA, Glass JD. Amyotrophic lateral sclerosis is a distal axonopathy: evidence in mice and man. Exp Neurol 2004;185:232-40.

72. Xin J, Wainwright DA, Mesnard NA, Serpe CJ, Sanders VM, Jones KJ. IL-10 within the CNS is necessary for CD4+ T cells to mediate neuroprotection. Brain Behav Immun 2011;25:820-9. 